\title{
Comparison of the Contents Pancasila Education and Citizenship From 1975-2013 Curriculum in Indonesian at The 21st Century
}

\author{
Gunawan Santoso, Mamun Murod, \\ University of Muhammadiyah Jakarta \\ mgunawansantoso@umj.ac.id, mamun.murod@umj.ac.id
}

\begin{abstract}
The study are philosophically Citizenship Education curricular subjects and is a learning tool creates learners who have mental Pancasilaist in word, deed and behavior in everyday life. Civics is the best material is original from Indonesia is not copied from other countries, including the Pancasila, the 1945 Constitution, the Republic of Indonesia, national unity, and the Red and White. The findings of this study also have implications for the development of scientific development theory and Citizenship Education in terms of the future of Indonesian high school curriculum. This research uses the method of literature analysis with grounded theory is a qualitative research method that uses a number of systematic procedures to develop a theory compiled inductive. Research grounded theory, this research inductive research techniques, emphasizes observation and develops a base of "intuitive" relationship practices between variables. The establishment of Citizenship Education in the Curriculum 1975 with the name of Moral Education Pancasila (PMP). The material is civics, national history, events after Indonesia's independence, the 1945 Constitution, each pancasila principle, the message of the importance of development (such as the five-year development plan and GBHN) for the Indonesian nation, specific state doctrines, discussing moral issues and so on, the vision of its mission is oriented towards value inculcation with the content of the values of Pancasila and the 1945 Constitution. In the 1984 PKn curriculum, Pancasila Moral Education (PMP) aims to strengthen morality and improve the ethics of students so that they can face and respond to all kinds of changes in living conditions in the future. Then the 1994 curriculum, where "Pancasila Moral Education" (PMP) has changed its name to "Pancasila education and citizenship" (PPKn). Curriculum in 2004, Initially the subjects were combined into one, because the content of Civic Education is derived from Pancasila itself. It is then broken down into its own subjects because Citizenship Education is considered important to be taught to students. Then PKn Curriculum in 2006, developed a body of knowledge known to have a systemic paradigm in which there are three domain citizenship education, namely academic domain, curricular domain, and socio-cultural domain. Furthermore, curriculum in 2013, Draft from Puskurbuk, Ministry of National Education in 2012, PKn 2006 will be changed to the lessons of Pancasila and Citizenship Education abbreviated PPKn.
\end{abstract}

Keyword: Curriculum, PPKn, years 1975-2013, $21^{\text {st }}$ century.

\section{Introduction}

The Covid-19 virus, which is currently endemic throughout the world, is attacking the human body's respiration. This virus is contagious and can infect anyone. Transmission through droplets of fluid that come from the respiratory tract and mouth, such as trouble that comes out when coughing or sneezing.(Faznur et al., 2020).

Indonesia's education curriculum has been growing since the period before 1947 until the curriculum in 2006, even the emergence of a new curriculum that will replace the old curriculum that is the curriculum in 2013. According to the Minister of Education and Culture or Minister of Education Muhammad Nuh (Kompas, $5 / 9 / 2012$ ) "There is no eternal curriculum. The curriculum is changing because of the changing times, not because the current curriculum is ugly or wrong. That's right in his day. But times change and we have to change."

The analysis is that the curriculum change process has no other purpose than to improve the quality of the learning process and the design of learning in schools so that students in Indonesia become quality resources in their time.

The name of the high school level CE curriculum from 1975-2013 in Indonesia is Curriculum Renewal (PK) (in 1975 and 1984), Process Skills Curriculum (KKP) (1994-19 Competency Based Curriculum (KBK) (2002-2004), Education Unit Level Curriculum (KTSP) (2006), Curriculum 2013 (KUTILAS) (2013). (Santoso, 2020). PKn powers in the 1975-1994 curriculum were on moral values as character formation, then in the 2004 
curriculum Civics lay in political power, while the strength of the PKn curriculum in 2006 was in the legal field, but in the 2013 curriculum there were combinations of these three forces that is carried out from moral, political, and legal values. (Santoso \& Sari, 2019). Civics solution through a process of learning and practice of students in the school are monitored and assessed as a form of moral evaluation and student behavior. Civics is the best material is original from Indonesia is not copied from other countries, including the Pancasila, the 1945 Constitution, the Republic of Indonesia, national unity, and the Red and White. (Santoso et al., 2013). Law No. 20 of 2003 on Indonesian national education system explains that national education has the function to develop the ability and shape the character and civilization of the nation dignified in order to educate the life of the nation. Further, in the chapter it is also explained that the purpose of national education to develop learners to become human beings who believe and fear to God Almighty, noble, healthy, knowledgeable, capable, creative, independent and become a citizen of a democratic and responsible.(Santoso, 2021b). Citizenship education is strongly influenced by the global world so that it can have an impact on the attitudes and mindset of learners in their daily lives. Thus the 21 st Century Citizenship Education develop civic competence which includes knowledge of civic knowledge, civic skills, and civic disposition are multidimensional. (Martini et al., 2019). An extensive literature has emerged through the last fifteen years in particular, around youth participation, civic engagement and citizenship. (Holdsworth \& Stokes, 2007). Young people's preparation for civic engagement and participation as citizens is receiving enhanced attention across the world. And rightly so, given the modest degree to which those entering young adulthood participate in politics and civic affairs in many world areas and the extent of their alienation.(Tibbitts \& Torney-Purta, 1999). The long, multidimensional crises in Indonesia have been rooted in degraded national morality. To improve this national moral quality, the country has needed a revitalisation of civic education's role in "value-based education" and "nation and character building". Therefore, civic education has developed to include contextual learning, which is assumed to improve students' character. (Komalasari, 2009).

Civics curriculum from year 1975-2013 are ultimately aims to make citizens say, act, and behave, based on Pancasila or spirit in everyday life that are run from the time school education to become a high school mature and become the pride of the nation bless yourself, family, school, state and nation with the moral soul/good and intelligent character who can advance and competitive in national and international era.(Santoso, 2019). It is hoped that the Cooperative Integrated Reading and Composition (CIRC) model can be used as an effort to improve the ability to understand the reading content of school students.(Kusumawardani et al., 2020). Growth, pro poor, pro job, and pro environment) proclaimed by President Susilo Bambang Yudhoyono in an introductory speech in the 2013 RAPBN (Tempo.co, 2009). What draws his ideas is to carry out the national development paradigm, the government wants to evaluate ( again) national education curriculum, especially from elementary to high school. The reason, according to the Minister of Education and Culture Muhammad Nuh, is "many problems in society are closely related to education", evaluation is intended to make learning more effective. For this reason, the government formed a curriculum evaluation team and asked various professions and expertise to conduct evaluations independently. (Santoso, 2021a).

According to some experts, curriculum changes from time to time, both in Indonesia and in other countries, are due to the needs of people who are always growing every year and the demands of the times that tend to change. Curriculum development is considered as a determinant of the future of the nation's children. Therefore, a good curriculum will be expected to be implemented in Indonesia so that it will produce a bright future for the nation's children that has implications for the progress of the nation and country.

According to some experts, curriculum changes from time to time, both in Indonesia and in other countries, are due to the needs of the community that is always growing every year and the demands of the era yaOne of the ideas of evaluating the curriculum is rolling fast after Vice President Boediono published the idea of education reform through the article "Key Education Development" Kompas, August 27, 2012 (Kompas Book, 2013: XIV). The article seems to be a description of the pillars of national development (pro growth, pro poor, pro job, and pro environment) proclaimed by President Susilo Bambang Yudhoyono in the introductory speech of the 2013 Rapbn. What is interesting is that the national development paradigm, the government wants to evaluate (again) the national education curriculum, especially elementary to high school level. The reason, according to Minister of Education and Culture Muhammad Nuh, "many problems in society are closely related to education", evaluation is intended to make learning more effective. Therefore, the government formed a curriculum evaluation team and asked for various professions and skills to conduct an independent evaluation (Kompas Book, 2013:XIII).

Minister of Education Muhammad Nuh, concerned about the violent behavior involving students (and students) that continues to rise lately, and thinks that the sagging of the school education curriculum is one of the causes of violence of these students, as well as education thinkers such as Ki Hajar Dewantara that education is a responsibility and work together with family institutions, community institutions, and school institutions. The process of social change and the formation of public civility may only occur optimally if the three pillars of 
education function in a balanced and proportionate manner according to their capacity (Kompas Book, 2013:XVI).

Therefore, the change of Citizenship Education curriculum is very important to be changed immediately in the world of education because it is the basis in the world of education towards smart and good citizens in the future as the ideals of education of the Republic of Indonesia. National Education System Law No. 20 of 2003 Article 37 states that "Citizenship Education must be contained in the curriculum of Primary and Secondary Education and Higher Education". Citizenship Education at various levels of education must be continuously improved and developed to equip learners with basic knowledge and abilities with regard to realizing citizens who can be relied upon by the nation and country.

\section{Methodology}

Research methodology is a technique to obtain the data needed in a research. Data sources are categorized into three groups. First, the source of printed materials (literature), including books, journals, papers and literature of research results on Citizenship Education. Second, the data source is an analysis document that includes the results of state documents on the content of the High School Citizenship Education curriculum from 1975-2013. Third, data sources of respondents (human resources), from Citizenship Education experts, lecturers, teachers and students. Data and information collection techniques used are qualitative data collection techniques that include documentation studies, literature studies and interviews. Meanwhile, the data analysis process used by researchers is data reduction, data display, verification and drawing conclusions (Miles and Huberman, 1992:16-18).

\section{Discussion}

The establishment of Citizenship Education in the Curriculum 1975 with the name of Moral Education Pancasila (PMP) as the name of the field of study for Civic Education whose purpose is to form pancasilaist citizens who believe and believe in God almighty. GBHN 1973 mandates the curriculum at all levels of education ranging from kindergarten to college, both public and private must contain Pancasila Moral Education, and enough elements to pass on the soul and values of 1945 to the younger generation. With the establishment of MPR Decree No. II/MPR/1978 concerning Guidelines for The Understanding and Practice of Pancasila (P4), the material in the field of study of Pancasila Moral Education is completed or even dominated by P4 materials and materials. Pancasila Moral Education (PMP) in the 1975 Curriculum. This name change occurred because the New Order wanted to make corrections to the Old Order, namely wanting to implement Pancasila purely and consequently. Therefore, the moral of Pancasila must be taught intensively through formal education, until PMP becomes its means. The material is civics, national history, events after Indonesia's independence, the 1945 Constitution, each pancasila principle, the message of the importance of development (such as the five-year development plan and GBHN) for the Indonesian nation, specific state doctrines, discussing moral issues and so on, the vision of its mission is oriented towards value inculcation with the content of the values of Pancasila and the 1945 Constitution.

In the 1984 PKn curriculum, Pancasila Moral Education (PMP) aims to strengthen morality and improve the ethics of students so that they can face and respond to all kinds of changes in living conditions in the future. PMP by Departments P and K (1982) stated that the nature of PMP is none other than the implementation of P-4 through formal education. This continued until the enactment of curriculum 1984 and curriculum 1994. The vision of its mission is oriented towards value inculcation with the content of the values of Pancasila and the 1945 Constitution (value inculcation is the improvisation of unavoidable indoctrination). P4 material in the study of citizenship education in PMP subjects is further strengthened in the Subject OF PMP Curriculum 1984. The description of the subject matter as PMP material is described in the order of the principles of Pancasila, as the description of P4 to the interpretation of the practice of Pancasila. Although the affective aspect became a heavy point in the PMP Curriculum 1984, the material discussed contained more aspects of knowledge (cognitive) when reviewing the subject matter such as human rights, principles and meanings of justice, the 1945 Constitution, state institutions, judicial bodies, Indonesian independence, international cooperation, and the study of Pancasila itself.

Then the 1994 curriculum, where "Pancasila Moral Education" (PMP) has changed its name to "Pancasila education and citizenship" (PPKn). Pancasila and Citizenship education is also intended as an effort to equip students with ethics, knowledge, and basic ability with regard to the relationship between fellow citizens, between citizens and the state, as well as preliminary education of state defense (PPBN) in order to become reliable citizens by the nation and state, in accordance with Law No. 2 of 1982 on Defense and Security, as well as circular of the Minister of Defense and Security SE/001/M/III/88. Pancasila and Citizenship (PPKn) whose contents still instill the values of Pancasila and Citizenship, but no longer emphasize on the values of Pancasila outlined into the P-4 points again, because it assumes that Pancasila is not only a simulation tool but must be implemented as well as possible in the life of society, nation and state. Furthermore, the scope of the 
curriculum in 1994 is (1). Values, morals and norms and behaviors are expected to be realized in the life of society, nation and state as referred to in the Guidelines for The Understanding and Practice of Pancasila. (2). The life of political, economic, social, cultural, defense, and security ideology as well as the development of science and technology in the container of unity of the unitary state of the Republic of Indonesia based on Pancasila and the 1945 Constitution. In the Supplement Curriculum in 1996 PKn only by adding material and not changing the name of the subject. Then in line with the political changes from the New Order to the Reformation Order, actually when the Curriculum of PPKn 1994, there was an adjustment of content. There are a number of content curriculum 1994 that is added and reduced, adapted to the spirit and nuances of reform. Around 1999, the curriculum of Pancasila and Citizenship Education (PPKn) with Supplements was born. A number of details and values of thought results related to ethics are accommodated into the PPKn Curriculum 1994 with Supplements. Thus, in 1999 when the reign of B. J. Habibie was born the term SCIENCE and IMTAK followed by the curriculum lmtak, its content is to integrate the value of religion into learning. But the values of Pancasila in P-4 is actually nothing wrong should be maintained because it is the spirit of pancasila that must be PKn review and deepen as the identity of ppkn lessons.

Curriculum in 2004, Initially the subjects were combined into one, because the content of Civic Education is derived from Pancasila itself. It is then broken down into its own subjects because Citizenship Education is considered important to be taught to students. This is because in Citizenship Education is taught broader citizenship material and the source is not only directly from Pancasila. Thus, the name change of PPKn changed to PKn. Citizenship Education Function in Competency Based Curriculum (KBK) with the name citizenship / Kn 2004 is: "To form smart citizens, skilled, and good character, and loyal to the nation and state of Indonesia based on Pancasila and the 1945 Constitution". The science materials of Citizenship Education subjects in the 2004 curriculum include the dimensions of knowledge, skills, and values. In line with the main idea of Citizenship Education subjects that want to form an ideal citizen, namely citizens who have faith and piety towards God almighty, knowledge, skills, and values in accordance with the concepts and principles of citizenship. In turn, good citizens are expected to help the realization of a constitutionally democratic society. While the scope of Citizenship subjects are grouped into components of the clumps of subject materials and subcomponents of the learning materials, namely: 1. Unity of nation and state; 2. Values and norms (religion, decency, decency and law); 3. Human Rights; 4. The needs of citizens' lives; 5. Power and politics; 6. Democratic society; 7. Pancasila and the state constitution; 8. Globalization; but this subject matter carries the mission of value and moral education.

Then PKn Curriculum in 2006, developed a body of knowledge known to have a systemic paradigm in which there are three domain citizenship education, namely academic domain, curricular domain, and sociocultural domain. These three domains have structural and functional connections tied by the conception of civic virtue and civic culture which includes civic knowledge, civic disposition, civic skill, civic confidence, civic commitment and civic competence. Subjects that focus on the formation of citizens who understand and are able to carry out their rights and obligations to become smart, skilled, and characterful Indonesian citizens mandated by Pancasila and the 1945 NRI Constitution. The purpose of PKn 2006 is to shape the character of critical, participatory, intelligent, rational and creative citizens in developing democratic life in relation to the life of the nation and in order to connect with other nations. To support this goal, contained as many as 8 studies of PKn namely Unity and Unity of the nation; Norms, laws and regulations; Human rights; The needs of citizens; Constitution of the State; Power and Politics; Pancasila; and Globalization.

Furthermore, curriculum in 2013, Draft from Puskurbuk, Ministry of National Education in 2012, PKn 2006 will be changed to the lessons of Pancasila and Citizenship Education abbreviated PPKn. Nomenclature is similar even can be said to be the same as the 1994 curriculum. Organizing the substance of curriculum, competency standards, basic competencies, and indicators of PPKn nationally by strengthening the values and morals of Pancasila; values and norms of the Constitution of the Republic of Indonesia year 1945; the value and spirit of Bhinneka Tunggal Ika; and insights and commitments of the Unitary State of the Republic of Indonesia. While the material scope of PPKn includes: 1. Pancasila, as the basis of the state, ideology, and life view of the nation, 2. The 1945 Constitution as a written basic law that becomes the constitutional basis of the life of society, nation, and state, 3. The Unitary State of the Republic of Indonesia, as the final agreement of the form of the Republic of Indonesia, 4. Bhinneka Tunggal Ika, as a form of philosophy of unity behind the diversity of social life, nation, and state.

\section{Conclusion}

The establishment of Citizenship Education in the Curriculum 1975 with the name of Moral Education Pancasila (PMP). The material is civics, national history, events after Indonesia's independence, the 1945 Constitution, each pancasila principle, the message of the importance of development (such as the five-year development plan and GBHN) for the Indonesian nation, specific state doctrines, discussing moral issues and so 
on, the vision of its mission is oriented towards value inculcation with the content of the values of Pancasila and the 1945 Constitution.

In the 1984 PKn curriculum, Pancasila Moral Education (PMP) aims to strengthen morality and improve the ethics of students so that they can face and respond to all kinds of changes in living conditions in the future. The description of the subject matter as PMP material is described in the order of the principles of Pancasila, as the description of $\mathrm{P} 4$ to the interpretation of the practice of Pancasila. Although the affective aspect became a heavy point in the PMP Curriculum 1984, the material discussed contained more aspects of knowledge (cognitive) when reviewing the subject matter such as human rights, principles and meanings of justice, the 1945 Constitution, state institutions, judicial bodies, Indonesian independence, international cooperation, and the study of Pancasila itself.

Then the 1994 curriculum, where "Pancasila Moral Education" (PMP) has changed its name to "Pancasila education and citizenship" (PPKn). There are a number of content curriculum 1994 that is added and reduced, adapted to the spirit and nuances of reform. Around 1999, the curriculum of Pancasila and Citizenship Education (PPKn) with Supplements was born. A number of details and values of thought results related to ethics are accommodated into the PPKn Curriculum 1994 with Supplements. Thus, in 1999 when the reign of B. J. Habibie was born the term SCIENCE and IMTAK followed by the curriculum lmtak, its content is to integrate the value of religion into learning. But the values of Pancasila in P-4 is actually nothing wrong should be maintained because it is the spirit of pancasila that must be PKn review and deepen as the identity of ppkn lessons.

Curriculum in 2004, initially the subjects were combined into one, because the content of Civic Education is derived from Pancasila itself. It is then broken down into its own subjects because Citizenship Education is considered important to be taught to students. The science materials of Citizenship Education subjects in the 2004 curriculum include the dimensions of knowledge, skills, and values. In line with the main idea of Citizenship Education subjects that want to form an ideal citizen, namely citizens who have faith and piety towards God almighty, knowledge, skills, and values in accordance with the concepts and principles of citizenship. In turn, good citizens are expected to help the realization of a constitutionally democratic society. While the scope of Citizenship subjects are grouped into components of the clumps of subject materials and subcomponents of the learning materials, namely: 1) Unity of nation and state; 2) Values and norms (religion, decency, decency and law); 3) Human Rights; 4) The needs of citizens' lives; 5) Power and politics; 6) Democratic society; 7) Pancasila and the state constitution; 8) Globalization; but this subject matter carries the mission of value and moral education.

Then PKn Curriculum in 2006, developed a body of knowledge known to have a systemic paradigm in which there are three domain citizenship education, namely academic domain, curricular domain, and sociocultural domain. To support this goal, contained as many as 8 studies of PKn namely Unity of the nation; Norms, laws and regulations; Human rights; the needs of citizens; Constitution of the State; Power and Politics; Pancasila; and Globalization.

Furthermore, curriculum in 2013, Draft from Puskurbuk, Ministry of National Education in 2012, PKn 2006 will be changed to the lessons of Pancasila and Citizenship Education abbreviated PPKn. While the material scope of PPKn includes: 1. Pancasila, as the basis of the state, ideology, and life view of the nation, 2. The 1945 Constitution as a written basic law that becomes the constitutional basis of the life of society, nation, and state, 3. The Unitary State of the Republic of Indonesia, as the final agreement of the form of the Republic of Indonesia, 4. Bhinneka Tunggal Ika, as a form of philosophy of unity behind the diversity of social life, nation, and state.

So the source of PKn material that has been taught in the curriculum in Indonesia from 1975-2013, can be classified into 3 sources of PKn root strength, namely:

1. Moral:

a) Integrate the value of religion into learning

b) The moral doctrine of statehood

c) The values of pancasila and the 1945 Constitution

d) Guidelines for The Implementation and Practice of Pancasila (P4)

e) The living needs of citizens

f) Values, morals and norms and behaviors that are expected to be realized in the life of society, nation and state, unity of nation and state,

g) Values and norms (religion, decency, decency and law)

h) Pancasila, as the basis of the state, ideology, and life view of the nation

i) Bhinneka Tunggal Ika, as a form of philosophy of unity behind the diversity of life

2. Law:
a) GBHN development message
b) Norms, laws and regulations, 
c) Human rights

d) Principles and meanings of justice

e) Pancasila and the state constitution

f) The 1945 Constitution as a written basic law that becomes the constitutional basis for the life of society, nation, and state

g) The Unitary State of the Republic of Indonesia, as the final agreement of the form of the Republic of Indonesia

3. Political:

a) Civics

b) History of nationality

c) Events after Indonesia's independence

d) Democratic society

e) Power and politics

f) Globalization

g) State institutions, judicial bodies, and international cooperation

h) The life of political, economic, social, cultural, defense, and security ideology as well as the development of science and technology in the container of unity of the unitary state of the Republic of Indonesia

\section{References}

Cholisin. (2006). Pemilihan kepala daerah dalam rangka perspektif peran PKn. Yogyakarta: Jurnal Civics, Volume 3, No. 2, Desember 2006.

Creswell. (2010). Research DesignPendekatan Kualitatif, Kuantitatif, dan Mixed (terjemahan). Yogyakarta: Pustaka Pelajar

Faznur, L. S., Santoso, G., \& Hidayati, N. (2020). Pemanfaatan Rempah-Rempah pada Era New Normal untuk Meningkatkan Imunitas Kekebalah Tubuh di Lingkungan Warujaya.

Holdsworth, R., \& Stokes, H. (2007). Civic Engagement and Young People A Report Commissioned by the City of Melbourne. Education, November.

Komalasari, K. (2009). The Effect of Contextual Learning in Civic Education on Students ' Civic Competence Kokom Komalasari Faculty of Social Science Education , Indonesia University of Education, Indonesia. Journal of Social Science, 5(4), 261-270. https://www.thescipub.com/abstract/?doi=jssp.2009.261.270

Kusuma, Deden Cahaya. (2013). Analisis Komponen-Komponen Pengembangan Kurikulum 2013. Bandung: Jurnal Analisis Komponen-Komponen Pengembangan Kurikulum Fakultas Pendidikan Matematika dan Ilmu Pengetahuan Alam Universitas Pendidikan Indonesia.

Kusumawardani, S., Diyanti, R., \& Santoso, G. (2020). Peningkatan Kemampuan Memahami Isi Bacaan dengan Model Pembelajaran Cooperative Integrated Reading and Composition ( CIRC ) pada Siswa Kelas VB di SDN Pondok Pinang 10. Seminar Nasional Penelitian LPPM UMJ, 1(23), 140-151.

Martini, E., Kusnadi, E., Darkam, D., \& Santoso, G. (2019). Competency Based Citizenship 21st Century Technology in Indonesia. International Journal of Recent Technology and Engineering, 8(1C2), 759-763. https://doi.org/10.35940/ijrte.b1483.0882s819

Santoso, G. (2019). Philosophical curriculum of civic education in 1975-2013 in indonesia 1). Prosiding Seminas FIP UMJ, 2(24), 236-249.

Santoso, G. (2020). THE STRUCTURE DEVELOPMENT MODEL OF PANCASILA EDUCATION ( PE ) AND CIVIC EDUCATION ( CE ) AT 21 CENTURY 4 . 0 ERA IN INDONESIAN Abstract: Kaywords : Proceedings of the 2nd African International Conference on Industrial Engineering and Operations Management Harare, i(i), 175-210.

Santoso, G. (2021a). Model Analysis ( SWOT ) of Curriculum Development From Civic Education at 21 Century , 4 . 0 Era in Indonesian. (International Journal of Entrepreneurship and Business Development), 04(02), 250-256.

Santoso, G. (2021b). THE PHILOSOPHICAL POWER OF CIVIC EDUCATION 21st. International Journal of Entrepreneurship and Business Development; IJEBD, 04(01), 72-79.

Santoso, G., Muchtar, S. Al, \& Karim, A. A. (2013). "Analisis Swot Kurikulum Pendidikan Kewarganegaraan Jenjang Sma Tahun 1975 - 2013."

Santoso, G., \& Sari, P. K. (2019). Proceedings of Educational Initiatives Research Colloquium 2019. Tibbitts, F., \& Torney-Purta, J. (1999). Citizenship education in Latin America: Preparing for the future. http://citeseerx.ist.psu.edu/viewdoc/download?doi=10.1.1.202.2087\&rep=rep1\&type=pdf

Udin Syaefudin Sa'ud dan Mulyani Sumantri. (2010). Pendidikan dasar dan menengah dalam (Ilmu dan aplikasi pendidikan). Bandung: Pedagogiana Press. 
Udin S. Winataputra. dan Budimansyah, D. (2007). Civic education: Landasan, konteks, bahan ajar dan kultur kelas. Bandung: Program Pascasarjana UPI.

Wahab, A.A., \& Sapriya. (2011). Teori dan Landasan Pendidikan Kewarganegaraan. Bandung. Alfabeta

Winarno. (2006). Pendidikan kewarganegaraan persekolahan: Standar isi dan pembelajarannya. Jurnal Civics, Volume 3, No. 1, Juni 2006, Jurusan PKn.H, FISE, UNY.

Winataputra, Udin Saripudin. (2012). Pendidikan Kewarganegaraan Dalam Perspektif Pendidikan Untuk Mencerdaskan Kehidupan Bangsa (Gagasan, Instrumentasi, Dan Praksis): Bandung. Widya aksara press.

Winataputra, Udin S dan Dasim Budimansyah. (2007). Civic Education Konteks, Landasan, Bahan Ajar, dan Kultur Kelas. Bandung: Program Studi Pendidikan Kewarganegaraan Pasca Sarjana Universitas Pendidikan Indonesia.

(2000). New paradigm and curriculum design for new Indonesian civic education. Paper The International Seminar: The Need for New Indonesian Civic Education, March 29, 2000, at Bandung. Pedagogiana Press.

(2007). Pendidikan Kewarganegaraan, dalam Ilmu dan aplikasi pendidikan. Bandung: (2007). Materi pelatihan dosen pendidikan kewarganegaraan. Jakarta: Dirjen Dikti, Depdiknas. 